\title{
The impact of internal control, cultural control, incentives, and work discipline on employee performance (Case study in PT Lestari Jaya Raya)
}

Luis Fernando $^{1 *}$, Dwi Asih Surjandari ${ }^{2}$

Departement of Accounting, Universitas Mercu Buana, Jakarta, Indonesia ${ }^{1,2}$

luis_santoso13@yahoo.co.id ${ }^{l}$,dwi.asih@mercubuana.ac.id ${ }^{2}$

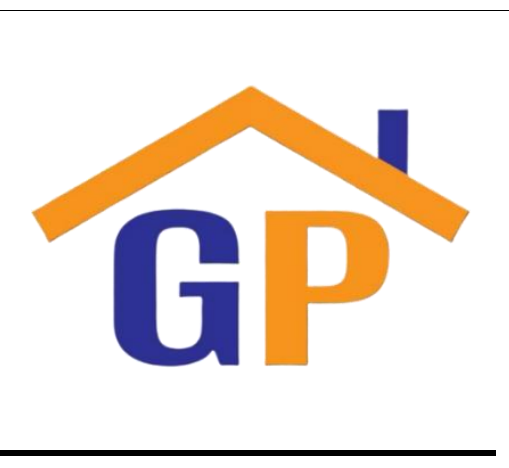

Article History

Received on 14 November 2021

$1^{\text {st }}$ Revision on 18 November 2021

$2^{\text {nd }}$ Revision on 17 December 2021

$3^{\text {rd }}$ Revision on 7 February 2021

Accepted on 8 February 2022

\begin{abstract}
Purpose: The goal of this research was to see how Internal Control, Cultural Control, Incentives, and work discipline affected Employee Performance at PT Lestari Jaya Raya.
\end{abstract}

Research methodology: The type of this research is a quantitative descriptive study that used a questionnaire to collect data. This study has a population, they were all employees of PT Lestari Jaya Raya with the sample in this study were office staff of 53 people.

Results: The results of this study showed that Cultural Control and Work Discipline had a positive impact on Employee Performance. Meanwhile, Internal Control and Incentives have no impact on Employee Performance. This means that the greater the Cultural Control and Work Discipline of the employee, the better the resulting Employee Performance

Limitations: This study is limited to the office staff of PT Lestari Jaya Raya so it has not described the overall condition of the employees of PT Lestari Jaya Raya which consists of office staff and operational staff.

Contribution: The results of this study are intended to be beneficial as management input, especially in the field of management accounting related to Employee Performance.

Keywords: Cultural Control, Employee Performance, Incentives, Internal Control, Work Discipline

How to cite: Fernando, L., and Surjandari, D, A. (2021). The impact of internal control, cultural control, incentives, and work discipline on employee performance (Case study in PT Lestari Jaya Raya). Annals of Management and Organization Research, 2(3), 209-223.

\section{Introduction}

Every company with a profit orientation would like to make a profit, to be able to generate good income is to pay attention to the assets of the company. One of the assets in a company is the company's employees. In improving employee performance there are several factors that can be considered so that the desired results of the company can be met. Some of these factors include internal control, cultural control, incentives, and work discipline.

AICPA (American Institute of Certified Public Accountants) emphasizes that internal control is critical for a variety of reasons, including protecting entities from human flaws and reducing the risk of errors and activities that are not in compliance with the rules. According to (Reginato \& Guerreiro, 2013) one of the elements that can boost employee performance is organizational culture. According to Robbins $\underline{(2010)}$, the values, ideas, traditions, and ways of working that are shared by organizational members and impact the way they act have been defined as organizational culture. According to Merchant and Van der Stede (2014), cultural control will work most effectively if group members have a social or emotional attachment to each other, so if the company has good cultural control, its employees will have good performance. Cultural controls are intended to support mutual monitoring; a group's strong 
pressure on individuals who deviate from the group's norms and values. In some cultures, such as Japan, incentives are used to avoid doing anything that might embarrass oneself or one's family. Furthermore, the incentives provided by the company can increase employee morale and performance to become even better (Oloke et al., 2017). According to Hasibuan (2007), incentives are extra remuneration given to specific employees whose performance exceeds the benchmark, with the incentive serving as a tool to reinforce the fair compensation concept. Work discipline, in addition to organizational culture and incentives, has an impact on employee performance (Permatasari, 2015). Work discipline is a management communication tool used by managers to persuade employees to change their behavior, as well as an attempt to raise awareness of prevalent social norms (Iskandar Rifai, V.V Rantung, 2016).

Furthermore, researchers conducted research on employees at PT Lestari Jaya Raya in this study. This is because based on information obtained from individuals who work at the company, there is a decrease in employee performance as evidenced by the late deadlines of several jobs in the company and the increase in complaints from customers for the services provided. Therefore, the researchers tried to examine what factors affect the performance of employees in the company. PT Lestari Jaya Raya is a freight forwarding company that handles both domestic and international shipments of commodities. This company is an expedition service company located in Cakung, East Jakarta.

Therefore, researchers are motivated to conduct research on this matter because it is quite important to know the impact of cultural control, incentives, and work discipline on employee performance. Based on this, the researchers conducted a study entitled "The Impact of Internal Control, Cultural Control, Incentives, and Work Discipline on Employee Performance (Case Study in PT Lestari Jaya Raya)"

\section{Literature review}

\section{Employee performance}

According to Benardin and Russell (2014), employee performance is the outcome of certain job tasks or activities performed at specific occupations over a period of time. Organizational behavior which is specifically linked to the production of goods or the provision of services is referred to as performance. Information on organizational performance is critical for determining whether the organization's performance process has met its expectations thus far. In reality, many organizations lack or only have sporadic information about performance within their organization. Performance is defined as the outcome of a person's or a group's job function/activities in an organization, as influenced by numerous elements, in order to meet organizational goals within a given time frame (Halim, Tjahcoyono, \& Hussein, 2000). Individual characteristics and organizational environmental factors are the two key aspects that might influence employee performance. Intrinsic motivation, skill flexibility, skill level, proactiveness, adaptability, and dedication are the primary individual determinants. Meanwhile, organizational environmental factors are related to work climate, work autonomy, and communication. According to Mathis (2002), the following are the indicators used to assess employee performance:

1) Quantity of work, the level of work produced in normal circumstances.

2) Quality of work, the form of accuracy, neatness, and linkage of results without ignoring the amount of work that has to be done.

3) Utilization of time, use of work time that is tailored to the needs of a firm or a government agency.

4) Cooperation, the ability to manage interpersonal interactions at work.

\section{Internal control}

Internal control, as described in perspective accounting, is a procedure that ensures an organization's objectives are met in aspects of improved operational efficiency, appropriate accounting reporting, and compliance with applicable laws, rules, and policies (Tackett, Wolf, \& Claypool, 2006). Internal control is a series of interrelated multi-layered activities on the normal organization's operational procedures with a goal of protecting sensitive information, reducing errors, and guaranteeing that such activities are carried out in accordance with the principles used (Chang et al., 2014). 
According to The Committee of Sponsoring Organization (COSO) (2013), there are five (5) components in internal control, namely:

1) Control environment

The control environment is a collection of standards, methods, and structures that serve as the foundation for establishing internal control throughout the business.

2) Risk assessment

External and internal threats pose different dangers to each business. Risk is described as the likelihood of an occurrence occurring that will obstruct the attainment of goals. Risk assessment is an ongoing and dynamic process for locating and evaluating threats to accomplishing objectives. The risk to the accomplishment of the objectives is considered relative or depends on the risk tolerance established by the entity. Thus, the premise for defining how the risk will be managed is to conduct a risk assessment.

3) Control activities

The activities of control are rules as well as techniques-based actions that help make sure managerial direction and decrease risks to achieving objectives. Control operations take place at all levels of the organization, as well as at various phases of the business process and in the technology environment. Authorization and approval, verification, reconciliation, and business performance assessment are all manual or automated processes.

4) Information and communication

The entity needs information in order to carry out its internal control activities and support the attainment of the entity's goals of management objectives using relevant information to aid the operation of other internal control components. Continuous communication gives and gets numerous types of data information. Internal communication is the key to the success of communicating information within a company.

5) Monitoring

Monitoring is a continuous, separate, or a combination of both evaluations accustomed to determining if each of the five internal control components exists and is operating.

The impact of internal control on employee performance has been studied previously, one of which is (Olufunmilayo \& Hannah, 2018); (Alawaqleh, 2021); (Sagala, 2020) which in his research shows that internal control has a positive effect on employee performance.

\section{$\mathrm{H}_{1}$ : Internal Control has a significant positive effect on Employee Performance.}

\section{Cultural control}

According to Robbins (2010), the values, ideas, traditions, and ways of working that are shared by organizational members and impact how they act have been defined as organizational culture. Merchant and Van Der Stede (2014) say that cultural control will work most effectively if group members have social or emotional attachments to one another. Corporate culture can be formed in several ways, namely:

1) Code of ethics

Code of Ethics is a formal written document that provides a general statement of the company's values, commitment to stakeholders, and management's wishes about how the company should function. Even though there are no particular rules, this code of conduct is intended to help employees understand what is expected of them. The Code may also Include key themes like a commitment to quality and customer happiness, employee and customer fairness, employee safety, innovation, risk-taking, and ethical standards are all important factors to consider, open communication, and a readiness to evolve. To be successful, formal training sessions, as well as informal discussions or mentorship meetings between employees and their supervisors, are required to reinforce the messages contained in this statement, however, some rules of conduct are ineffective because they lack strong leadership.

2) Group rewards

Cultural control is also aided by the provision of rewards or incentives based on communal achievement. Plans for incentives can take many forms, such as bonuses, profit sharing or profitsharing arrangements in which employees are compensated depending on the company's or entity's overall success. In this cultural control, the reward given is in the form of group rewards. 
These types of group incentives can help to motivate people to work together, new employee onthe-job training (when they are tasked with the same group with experienced colleagues), and encourage employees to actively work for the good of the group by applying peer pressure.

\section{EM in the banking sector}

3) International reporting standards enhance the accounting systems of all companies worldwide. However, like any other regulation system, these standards allow managers to manipulate revenues and costs to change earnings or accomplish other plans. Also, academic research on this particular topic of earnings management has received considerable attention in recent years, especially after the financial crises of the 2000s. For Schipper (1989), managerial intentions to manipulate the financial reporting process are driven by pursuing private gains. Generally, earnings management practices are used for three purposes, income smoothing, signaling, and capital management. In other words, earnings management practices help managers reduce the net income changes through a financial year, signal private future financial information about future earnings levels to specific investors, and raise the capital ratio to comply with local and international standards. Ceccobelli \& Gliosi (2019) concluded that income smoothing is a practice well used in the banking industry in order to reduce the reported income changes' variance by choosing specific accruals. Another approach to shaping corporate culture

Other common approaches to shaping corporate culture include:

- Inter-company transfers or employee rotation

Support improve staff socialization to propagate the culture within the company, appreciating them for the more diverse issues faced by the company, and preventing the creation of goals from conflicting views. Transfers also have the potential to mitigate employee fraud by preventing personnel from becoming "overly acquainted" with specific businesses, activities, coworkers, and/or transactions.

- Physical setting

Physical settings, in addition, to help with corporate cultures, such as office plans, architecture, interior decor, dress code, institutionalized habits, behavior, and vocabulary.

- The tone of the top

The existence of a management statement must be congruent with the culture they are cultivating, as well as their attitudes and behavior. In this case, managers play an important role to be a determining factor in creating cultural integrity within the company.

Further, according to Robbins (2010), there are several dimensions that describe cultural control:

1) Attention to detail

How the level of thoroughness, analysis, and attention to detail does the company expect from its employees

2) Result orientation

How much emphasis is placed on accomplishing goals (outcomes) rather than how to achieve goals by the company (processes).

3) Individual orientation

How much emphasis does the organization place on the human component (workers) while making management decisions

4) Team orientation

In completing tasks, how much does the company value group (team) work over individual work

Thus, if cultural control is carried out properly and effectively with existing approaches, it can improve the performance of the employees of the company. This is shown in research conducted by (Reginato \& Guerreiro, 2013); (Hormati, 2016) which shows that cultural control has a positive effect on employee performance.

\section{$\mathrm{H}_{2}$ : Cultural Control has a significant positive effect on Employee Performance.}

\section{Incentives}

According to Banjoko (2006) incentives are described as prizes given when an organization's established goals are met. It can also be considered as a payment made to employees based on the 
amount of output or work achieved. Incentives are a type of motivation that encourages employees to work to their full potential by providing additional cash above and beyond the payor wages that have been set. Incentives are given to employees and their families in order to meet their demands. Wage payment plans tied directly or indirectly to various standards of employee performance or organizational profitability are referred to as incentive systems (Iskandar Rifai, V.V Rantung, 2016). Compensation and incentives are inextricably linked; incentives are components of compensation, and both are critical in attaining the organization's overall goals and objectives. Employees whose performance exceeds the stated requirements can be given incentives in the form of sufficient remuneration. Employee incentives are a motivator for them to work harder so that their performance improves. According to Hasibuan (2007), states that incentives are additional remuneration given to specific individuals whose performance is above average and that this incentive is a technique used to promote the fair compensation concept.

The goal of offering incentives is to satisfy the needs of numerous stakeholders, Hariandja (2002):

1) For corporations:

a) Cultivating a skilled and capable team that is very loyal to the organization

b) Keep and improve employee morale, which has been found to reduce labor turnover and absenteeism

c) Increase productivity which correlates to more units produced per unit time and more sales

2) For workers:

a) Enhancing the standard of living by earning additional compensation in addition to the basic salary

b) Enhancing employee morale so as to inspire them to improve their abilities

\section{Board of directors}

Literature review asserts that the board of directors is the most efficient dispositive to supervise and control managers. However, earlier studies asserted that the board size could influence the monitoring process of a bank manager, while other academic research concluded that there is a negative association between board size and managers' opportunistic behaviors. Therefore, the board's size could be an essential variable to ensure the effectiveness of the corporate governance system, especially in the banking industry where the regulatory framework and the macroprudential supervision are present. Indeed, Levine (2004) highlighted the three factors making the banking governance more special than firms. To begin, banks' opaqueness amplifies information asymmetry and makes incentive arrangements that match managers' interests with those of banks' equity holders more challenging to create. Second, increased informational asymmetries obstruct the efforts of dispersed equity and debt investors to supervise bank executives effectively. Third, legal limitations on bank ownership concentration prevent outsiders from acquiring a significant proportion of bank shares and exercising governance as concentrated shareholders. Finally, the existence of a deposit insurance system lowers depositors' incentives to supervise banks effectively and encourages banks to operate with a high degree of leverage, which increases the bank's risk exposure. Thus, the importance of the governing body arises under these circumstances.

Vasilakopoulos, Tzovas, \& Ballas (2018) state that the board of directors' oversight role may have specific consequences on managers' accounting discretion. Accounting statistics is a critical source of information for a board's decision-making. As a result, the board of directors will need comparable and verifiable financial data in order to make decisions and supervise management. Therefore, managers who are aware that their accounting discretion is being carefully scrutinized will abstain from manipulating financial statements.

Board size

According to the agency theory, a large board fosters conflicts of interest between the management and shareholders, mostly due to coordination and communication problems that may impede consensus decision-making (Jensen, 1993). This situation is the most opportunistic to managers willing to use their discretionary behaviors to maximize their wealth by using EM techniques, especially when they dominate other board members by numbers (Lipton \& Lorsch, 1992). However, the resource dependency theory contradicts the size restrictions made by the agent-principal theory because a large 
board of directors acquires the necessary competencies broth by the different administrators. Therefore, the more a board's size amplifies, the more the governance system's overall quality of monitoring and supervising enhances.

Meanwhile, in accordance with Merchant and Van der Stede (2014) the purpose of incentives is divided into three, namely:

1) Information

Cost, quality, customer service, asset management, and expansion are all factors to consider are all areas where rewards call attention to and inform or alert people about the relative importance of often competing for result areas. Simply informing employees that customer service is important, for example, may have an impact on their behavior.

2) Motivation

Some employees require incentives to motivate them to put in the extra effort necessary to do a good job, in this example, to work hard, perform an excellent job, and be successful. In other words, the goal of incentives is frequently referred to as a goal that motivates people to work more.

3) Attract and retain workers

For many employees, performance-based benefits are a significant part of their complete remuneration package. Some incentives are guaranteed due of the company wants to improve its staff recruiting (selection) and retention processes by giving packages that are equivalent to or better than those offered by competitors, or by tying payments to employee retention.

\section{Work discipline}

Discipline refers to a person's willingness to follow and obey the rules that govern his environment. Strong employee discipline will benefit the organization to achieve its objectives better, however, bad staff discipline will have a negative impact act as a roadblock, and slow down the company's progress. Discipline is needed for both the individual concerned and the organization. For illustrate, if an errand boy in an office arrives late, the office workspace is disrupted since no employees are available to do their tasks, causing the process to be disrupted that day. From this example, we can see that someone's indiscipline can damage organizational activities. Employees with bad work discipline have a condition or attitude of respect for company rules and regulations. If the firm's current policies or requirements are ignored or frequently broken, the employee has poor work discipline. On the other hand, if the employee complies with the company's provisions, it illustrates the existence of a good discipline condition. In a narrower and more widely used sense, discipline means actions taken with supervision to correct wrong behaviors and attitudes of temporary employees (Siagian, 2006).

According to Singodimedjo (2012), the factors that influence work discipline are:

1) The size of the compensation

The amount of compensation a person receives can have an impact on their ability to maintain discipline. Employees will follow all legal regulations if they believe they are being fairly compensated for their contributions to the corporate. They will be able to work peacefully if the employee is adequately compensated, diligently, and to give it their all at all times. If he feels that the pay he receives is insufficient, he will think twice and try to locate other sources of income outside of the company, prompting him to frequently fail and beg permission to quit.

2) Exemplary leadership in the company

The role of exemplary leadership has a lot of clout in the company, in comparison to all the other factors that influence company discipline, it is much more powerful because the leadership in a company is still a role model for employees. The subordinates would always imitate what they saw every day. Whatever the leader does. As a result, if a Leader wants the organization to be disciplined, he must first model it for others to follow.

3) Definite rules that can be used as a guide

Employees will be willing to discipline if there are clear rules and they are informed. If the rules of discipline are only according to the taste of the leader or apply to certain people, do not expect that employees will obey the rules. Therefore, discipline will be enforced in a company, if there are written rules that are mutually agreed upon. Thus, employees will get a certainty that anyone and anyone needs to be penalized indiscriminately. 
4) Leadership courage in taking action

With action against discipline violators, in conformity with current punishment, all personnel will have a positive attitude, safe, and they will swear in their hearts that they will not repeat the mistake. In such a circumstance, all employees will be completely spared from reckless attitudes, as long as they want to be on their own in the company. Conversely, if the leadership does not dare to take action, even though it is confirmed that the employee violates discipline, but is not reprimanded/punished, it will have an impact on the company's working environment. Employees will say: "What is the discipline for, while people who violate discipline alone are never penalized."

5) Leadership supervision

The most appropriate person to carry out supervision of this discipline is of course the direct supervisor of the employees concerned. This is because the direct superiors are the ones who know the most and are closest to the employees under them. Supervision carried out by direct superiors is often called waskat. At whatever level he feels, then a leader is responsible for carrying out this inherent supervision so that the tasks assigned to subordinates do not deviate from what has been set.

6) Attention to employees

Employees want to hear their complaints and issues and find a solution, which is really needed by employees. Leaders that are able to pay close attention to their staff will be able to instill good work ethics. Because the employee is not only physically close but also emotionally close and close distance in terms of inner distance. Such leaders' employees will always respect and appreciate so that it will have a major impact on performance and employee morale.

7) Created habits that support the establishment of discipline

With good leadership, a leader can do much to create a work climate that allows enforcement of discipline as a natural process, as employees will accept and comply with rules and policies as a safeguard for their job success and personal well-being.

Thus, if an employee is disciplined in carrying out his work, the results of the employee's performance will be even better. This is shown in research conducted by (Ida Aryati, 2017); (Fathia et al., 2018) that work discipline has a positive effect on employee performance.

\section{$\mathrm{H}_{4}$ : Work Discipline has a significant positive effect on Employee Performance.}

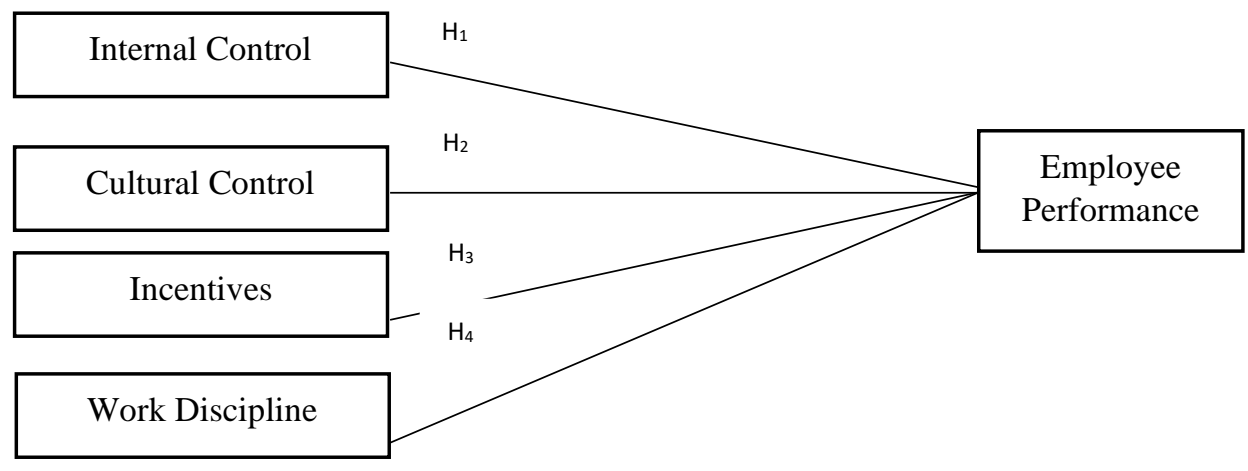

Figure 1. Framework of thought

\section{Research methodology}

\section{Type of research}

This type of research is a quantitative descriptive research. Descriptive research uses sample or population data to characterize or provide an overview of the object under study. While quantitative research is systematic scientific research on parts and phenomena and their relationships (Sugiyono, 2015). The data used in this study is primary data, namely data obtained directly from the object under study. 


\section{Technique of data collection}

The data collection technique used is a questionnaire. The questionnaire is a list of written statements that have been formulated previously and which respondents will answer. Questionnaires were given to office employees at PT Lestari Jaya Raya about the Effect of Cultural Control, Incentives, and Work Discipline on Employee Performance. Data analysis is carried out if the data to be used has been collected and then analyzes the data based on the appropriate method to be used. Data analysis and management activities are carried out by giving and adding up the weights of the answers to each of the variables contained in the questionnaires that have been distributed. The sampling technique used in this study is convenience sampling. This technique is used for sampling based on certain considerations. The considerations used as requirements in determining the sample are as follows: (a) are employees of the office of PT Lestari Jaya Raya (b) research subjects are pleased to fill out research questionnaires. In this study, the authors used the analysis technique of the respondent's level of agreement. In measuring the level of agreement using a scale developed from the Likert scale which is an interval scale. The scale in this study uses a 5-point scale that is given a weighted value, as shown in the following table:

Table 1. Scale of Likert

Source: (Sugiyono, 2015)

\begin{tabular}{|c|c|}
\hline Answer & Score \\
\hline Strongly Agree & 5 \\
\hline Agree & 4 \\
\hline Neither Agree or Disagree & 3 \\
\hline Disagree & 2 \\
\hline Strongly Disagree & 1 \\
\hline
\end{tabular}

This first stage of our analysis serves to measure the EM proxy. Generally, LLPs are divided into two components, discretionary LLP (DLLP) and non-discretionary LLP (NDLLP) (Ben Othman \& Mersni, 2014). The second component seeks to cover the anticipated loss in the bank's loan portfolio or nonperforming loans due to business cycles and changes. While the first represents the part of total accruals engaged by changes in bank business conditions and accounting manipulations to change in earnings volume. According to Ben Othman \& Mersni (2014), the only way to estimate NDLLP is through the variables reflecting the level of loss in a bank's loan portfolio.

Following the approach used by Kanagaretnam, Lobo, \& Mathieu (2004), Kwak, Lee, \& Eldridge (2009), Taktak et al., (2010), and Ben Othman et Mersni (2014), which consist of estimating the DLLP level by using the one-year lagged level of non-performing loans, or the begging balance of NPL in a fiscal year, annual changes in NPL and total loans' volume. The logic behind this prediction is using LLP as a dependent variable and NDLLP characteristics as independent variables to detect the DLLP.

\section{Population and sample}

The population is a generalized region that consists of objects/subjects with specific attributes and characteristics that researchers choose to study and derive conclusions from (Sugiyono, 2015). PT Lestari Jaya Raya has 250 employees who are divided into 2 groups. The first group is employees in the operational field (warehouse, driver, courier) and the second group is employees who work in the office (office staff, supervisor, manager). The population in this study is all employees who work at PT Lestari Jaya Raya a total of 250 people.

The sample is a representation of the population's size and features (Sugiyono, 2015). Based on this understanding, the subjects who are the sample in this study are office employees with 53 respondents.

\section{Methods of analysis}

The method of analysis used in this study by using the Partial Least Square (PLS) approach. Partial Least Square is a powerful data analysis method and is often also referred to as soft modeling and is often also referred to as variance or component-based structural equation modeling (Ghozali and Latan, 
2015). PLS-SEM is well suited to use in research that tries to establish a theory since it aims to evaluate the predictive link between components by examining whether there is a relationship or impact between the constructs. A latent variable is defined as a linear aggregate of its indicators in the formal PLS model. How the inner model (structural model that connects latent variables) and outer model (measurement model that is the relationship between indicators and constructs) are described determines the weight estimate for the latent variable score component. The residual variance of the dependent variable is the outcome. The weight estimate used to construct the latent variable score is the first of three types of parameter estimations obtained using PLS. Second, it represents the estimated route between the latent variable and the indicator (loading). Third, related to the means and location of parameters (values of regression constants) for indicators and latent variables. PLS employs a threestep iteration procedure to generate these three estimates, with each stage producing one estimate. The first stage produces estimates for the outer model and inner model, and the third stage produces means estimates (Ghozali and Latan, 2015).

\section{Outer Model Test}

According to Ghozali and Latan (2015) the measurement Structural equation model, also known as Confirmatory Factor Analysis (CFA), is used to measure the model using the model test. CFA is used to determine a construct's dimensionality. The measuring model's evaluation was carried out to assess the model's validity and dependability. The construct validity test in PLS was carried out through Convergent Validity, Discriminant Validity, and Average Variance Extracted (AVE) tests. The reliability test was carried out to demonstrate the instrument's consistency, accuracy, and consistency in measuring the construct. There are two techniques to assess the reliability of a concept using reflexive indicators, namely Cronbach's Alpha and Composite Reliability a construct

\section{Inner Model Test}

Based on substantive theory, the Inner Model (inner relation, structural model, and substantive theory) defines the link between latent variables. R-square for the dependent construct and t-test, as well as the significance of the coefficients of the structural path parameters, were used to assess the structural model. (Ghozali dan Latan, 2015)

\section{Research findings and discussion Statistics descriptive}

The following is a recapitulation of the results of the descriptive analysis for each research variable.

Table 2. Analysis descriptive

\begin{tabular}{|l|c|c|c|c|c|}
\hline & $\begin{array}{c}\text { Internal } \\
\text { Control } \\
\text { (X1) }\end{array}$ & $\begin{array}{c}\text { Cultural } \\
\text { Control } \\
(\mathbf{X 2})\end{array}$ & $\begin{array}{c}\text { Incentives } \\
\text { (X3) }\end{array}$ & $\begin{array}{c}\text { Work } \\
\text { Discipline } \\
(\mathbf{X} 4)\end{array}$ & $\begin{array}{c}\text { Employee } \\
\text { Performance } \\
(\mathbf{Y})\end{array}$ \\
\hline Mean & 4,229 & 4,329 & 3,830 & 4,324 & 4,173 \\
\hline Median & 4 & 3 & 2 & 3 & 2 \\
\hline Min & 1 & 2 & 1 & 2 & 2 \\
\hline Max & 5 & 5 & 5 & 5 & 5 \\
\hline
\end{tabular}

Source: Output Smart PLS 3.0

Table 2 above shows that the average value of the variable Internal Control is 4.229. This indicates that the average respondent agrees with the statement on the questionnaire related to internal control. Furthermore, the average value of the cultural control variable is 4.329. This indicates that the average respondent agrees with the statement on the questionnaire related to cultural control. Furthermore, the average value of the incentive variable is 3.830. This indicates that the average respondent is neutral with the statements on the questionnaire related to incentives. Furthermore, the average value of the work discipline is 4.324. This indicates that the average respondent agrees with the statement on the questionnaire related to work discipline. Furthermore, the average value of the employee performance variable is 4.173 . This indicates that the average respondent agrees with the statement on the questionnaire related to employee performance 


\section{Outer Model}

The outer model test is carried out to be certain that the measurement utilized may be used as a measurement, in the sense of being valid and reliable. In the analysis of the outer model there are several indicators, namely:

1. Convergent validity

2. Average Variance Extracted (AVE)

3. Discriminant validity

4. Cronbach alpha and Composite reliability

\section{Convergent validity}

The outer model outlines how each indicator relates to its latent variables, while convergent validity establishes the link between latent variables and their indicators. The value of the loading factor on the latent variable with its indications is the degree of convergent validity. Expected value $>0.7$ (Ghozali and Latan, 2015).

The following are the results of the Convergent validity test

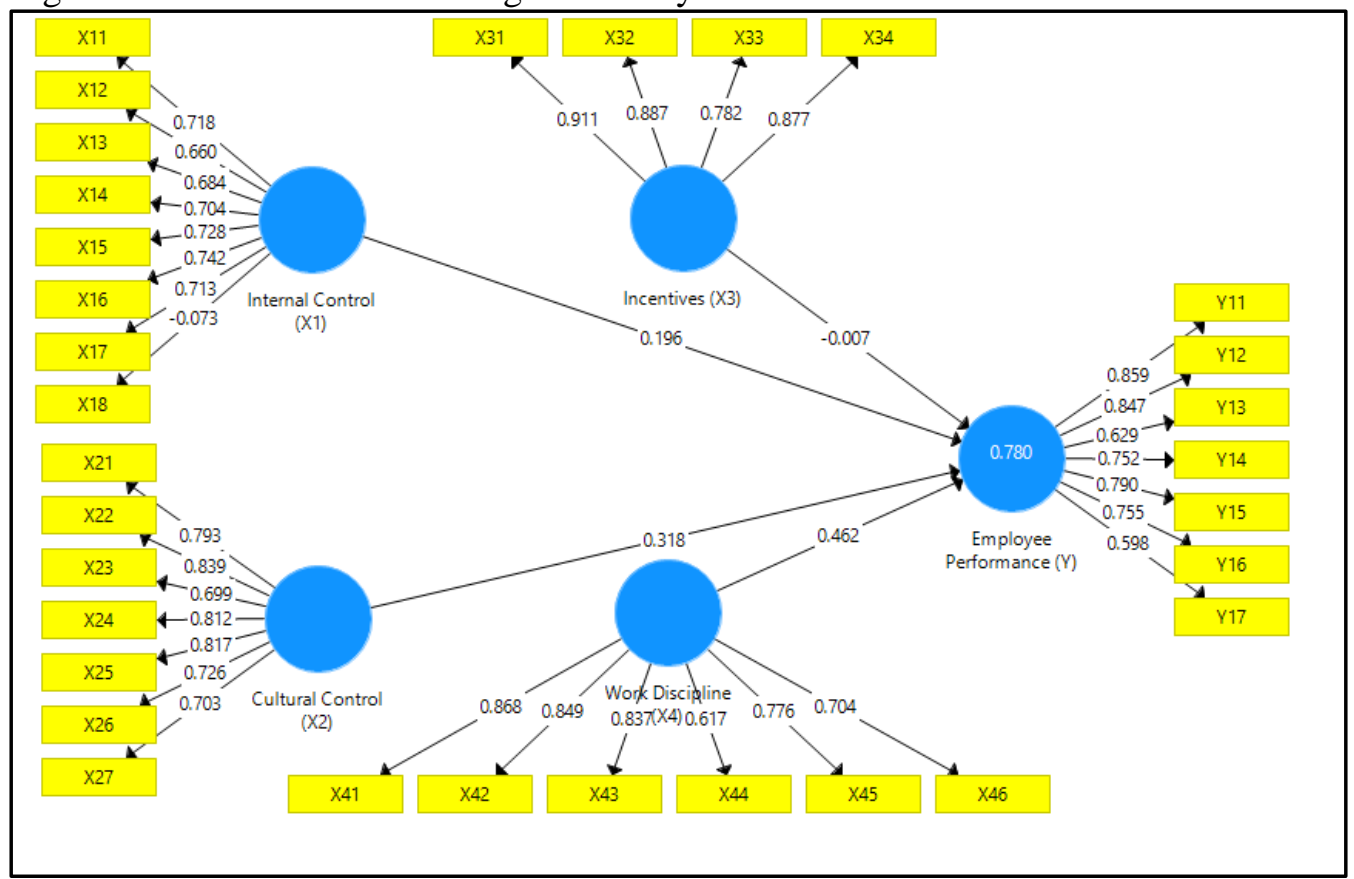

Figure 2. Convergent validity

Source: Output Smart PLS 3

Based on the figure above, it can be concluded that all indicators have values above 0.7. Then the research can be continued to the next stage.

Average Variance Extracted (AVE)

Apart from being seen from the factor loading value, convergent validity can also be seen from the Average Variance Extracted (AVE) value. AVE is the average of the variance extracted which is the square of the standardized loading of each indicator that explains the latent variable. The expected AVE value is greater than 0.5 . 
The following are the results of the AVE test.

Table 3. Average Variance Extracted (AVE) Test

Source: Output Smart PLS 3.0

\begin{tabular}{|c|c|}
\hline & $\begin{array}{c}\text { Average Variance Extracted } \\
(\text { AVE) }\end{array}$ \\
\hline Internal Control $(\mathrm{X} 1)$ & $\mathbf{0 , 5 5 1}$ \\
\hline Cultural Control $(\mathrm{X} 2)$ & $\mathbf{0 , 7 2 7}$ \\
\hline Incentive $(\mathrm{X} 3)$ & $\mathbf{0 , 7 4 9}$ \\
\hline Work Dicipline $(\mathrm{X} 4)$ & $\mathbf{0 , 7 4 9}$ \\
\hline Employee Performance $(\mathrm{Y})$ & $\mathbf{0 , 6 6 8}$ \\
\hline
\end{tabular}

Based on the table above, it can be concluded that all indicators have a value above 0.5 which is the minimum value for the AVE test (Ghozali and Latan, 2015). Then the research can be continued to the next stage.

Discriminant validity

This is a cross-loading factor number that may be used to see if the construct has enough discriminant power, namely by comparing the loading value on the intended construct to the loading value on other constructions, which must be larger (Ghozali and Latan, 2015). The cross-loading table can be used to assess discriminant validity.

The following are the results of the discriminant validity test.

Table 4. Discriminant validity test

\begin{tabular}{|c|c|c|c|c|c|}
\hline & $\begin{array}{c}\text { Internal Control } \\
\text { (X1) }\end{array}$ & $\begin{array}{c}\text { Cultural } \\
\text { Control } \\
\text { (X2) }\end{array}$ & Incentives (X3) & $\begin{array}{c}\text { Work } \\
\text { Discipline } \\
\text { (X4) }\end{array}$ & $\begin{array}{c}\text { Employee } \\
\text { Performance } \\
\text { (Y) }\end{array}$ \\
\hline $\mathrm{X} 11$ & 0.741 & 0.507 & 0.443 & 0.322 & 0.543 \\
\hline $\mathrm{X} 14$ & 0.717 & 0.589 & 0.425 & 0.597 & 0.590 \\
\hline $\mathrm{X} 15$ & 0.754 & 0.452 & 0.603 & 0.272 & 0.449 \\
\hline $\mathrm{X} 16$ & 0.770 & 0.485 & 0.572 & 0.245 & 0.433 \\
\hline $\mathrm{X} 17$ & 0.729 & 0.430 & 0.414 & 0.197 & 0.464 \\
\hline $\mathrm{X} 21$ & 0.616 & 0.887 & 0.603 & 0.553 & 0.788 \\
\hline $\mathrm{X} 22$ & 0.579 & 0.860 & 0.617 & 0.637 & 0.697 \\
\hline $\mathrm{X} 24$ & 0.505 & 0.866 & 0.462 & 0.757 & 0.720 \\
\hline $\mathrm{X} 25$ & 0.591 & 0.794 & 0.408 & 0.619 & 0.625 \\
\hline $\mathrm{X} 31$ & 0.607 & 0.490 & 0.909 & 0.360 & 0.499 \\
\hline $\mathrm{X} 32$ & 0.491 & 0.513 & 0.884 & 0.380 & 0.527 \\
\hline $\mathrm{X} 33$ & 0.615 & 0.477 & 0.786 & 0.440 & 0.392 \\
\hline $\mathrm{X} 34$ & 0.577 & 0.641 & 0.878 & 0.543 & 0.559 \\
\hline $\mathrm{X} 41$ & 0.421 & 0.682 & 0.336 & 0.879 & 0.779 \\
\hline $\mathrm{X} 42$ & 0.382 & 0.650 & 0.455 & 0.891 & 0.599 \\
\hline $\mathrm{X} 43$ & 0.389 & 0.646 & 0.479 & 0.878 & 0.643 \\
\hline $\mathrm{X} 45$ & 0.402 & 0.609 & 0.484 & 0.812 & 0.582 \\
\hline $\mathrm{Y} 11$ & 0.560 & 0.774 & 0.538 & 0.705 & 0.888 \\
\hline $\mathrm{Y} 12$ & 0.565 & 0.685 & 0.499 & 0.644 & 0.862 \\
\hline $\mathrm{Y} 14$ & 0.474 & 0.661 & 0.295 & 0.547 & 0.723 \\
\hline $\mathrm{Y} 15$ & 0.614 & 0.675 & 0.485 & 0.516 & 0.830 \\
\hline $\mathrm{Y} 16$ & 0.562 & 0.602 & 0.525 & 0.685 & 0.770 \\
\hline $\mathrm{S}$ & & & & \\
\hline
\end{tabular}

Source: Output Smart PLS 3.0 
From the table above, it can be seen that the correlation between the cultural control constructs, incentives, work discipline, and employee performance all indicators are all higher in value than the other constructs. All loading factor values for each indicator of each latent variable already have the largest loading factor value compared to other variable loading factor values so that it can be concluded that all latent variables have good discriminant validity.

\section{Composite reliability and Cronbach's Alpha}

To ensure that there are no measurement-related problems, the final step in evaluating the outer model is to test the unidimensionality of the model. The unidimensionality test was carried out using composite reliability indicators and Cronbach's alpha. For these two indicators, the cut-off point is 0.7 for composite reliability and Cronbach's alpha (Ghozali and Latan, 2015).

The following are the results of testing Composite Reliability and Cronbach's Alpha Table 5. Composite Reliability and Cronbach's Alpha Test

\begin{tabular}{|l|c|c|}
\hline & Cronbach's Alpha & Composite Reliability \\
\hline Internal Control (X1) & 0.769 & 0.841 \\
\hline Cultural Control (X2) & 0.887 & 0.911 \\
\hline Incentives (X3) & 0.888 & 0.923 \\
\hline Work Discipline (X4) & 0.870 & 0.902 \\
\hline Employee Performance (Y) & 0.870 & 0.900 \\
\hline
\end{tabular}

Source: Output Smart PLS 3.0

Based on the table above, it can be seen that all composite reliability and Cronbach's Alpha indicators have minimum values above 0.7 (Ghozali and Latan, 2015). Thus, all modified constructs have been declared valid and reliable so that they can proceed to the Inner Model testing.

\section{Inner Model}

The inner model test was carried out with the aim of seeing whether the relationship between variables, namely exogenous (independent) and endogenous (dependent) constructs was able to provide answers to questions regarding the relationship between variables that had been hypothesized previously.

Coefficient of determination $\left(R^{2}\right)$

Coefficient determination or $\mathrm{R}$ square $\left(\mathrm{R}^{2}\right)$ is performed to assess the model's capacity to explain fluctuations in the dependent variable. When $\mathrm{R}^{2}$ approaches, independent variables give practically all of the information needed to predict changes in the dependent variable.

The following are the results of the coefficient of determination in this research: Table 6. Coefficient determination test
R-square
0.770

\section{Source: Output Smart PLS 3.0}

Based on the test results, it can be concluded that the variability of employee performance constructs that can be explained by the variability of the constructs of internal control, cultural control, incentives, and work discipline is $77 \%$ while $23 \%$ is explained by other variables outside the study (Ghozali and Latan, 2015)

\section{Goodness of Fit Test}

To determine the feasibility of the model in this study, the researchers conducted goodness of fit test with the following formula: 


$$
G o F=\sqrt{\overline{A V E} \times \overline{R^{2}}}
$$

From the data obtained, the resulting GoF value $=0.73$

Thus, the Goodness of Fit value is included in the large category because it is greater than 0.36 and can be continued to test the hypothesis (Ghozali and Latan, 2015).

\section{Hypothesis test}

The results of the hypothesis test must have a probability value of $<0.05$ so that it can be concluded that between variables has a significant influence (Ghozali and Latan, 2015). The results of hypothesis testing can be seen in the following table:

Table 7. Hypothesis Test

\begin{tabular}{llll}
\hline \hline Variable & $\begin{array}{l}\text { Original } \\
\text { Sample }\end{array}$ & T-Statistic & P Values \\
\hline \hline Internal Control & 0.251 & 1.760 & 0.079 \\
Cultural Control & 0.422 & 2.032 & 0.043 \\
Incentives & -0.015 & 0.137 & 0.891 \\
Work Discipline & 0.337 & 2.859 & 0.004 \\
\hline \hline
\end{tabular}

Source: Output Smart PLS 3.0

Based on the table above, the researchers have the following conclusions:

1) The internal control variable has no significant effect on employee performance.

2) The cultural control variable has a significant influence on employee performance.

3) The incentive variable has no significant effect on employee performance.

4) Work discipline variable has a significant influence on employee performance

\section{Conclusion}

The conclusions obtained from the hypothesis testing that has been carried out are:

1) Internal control variables have no effect on employee performance at PT Lestari Jaya Raya because the internal control system implemented by PT Lestari Jaya Raya has not been implemented or implemented effectively and efficiently so that it causes a lack of results from the performance of each employee produced.

2) The independent variable of cultural control has a positive effect on employee performance because PT Lestari Jaya Raya often holds job rotations so that employees do not feel bored so that employee performance is maintained. PT Lestari Jaya Raya also often holds family events such as breaking fast during the fasting month so that there is a social bond between employees in the company.

3) The independent variable incentives have no effect on employee performance at PT Lestari Jaya Raya because the company does not maximize the incentive system and the distribution of incentives is not significant. This makes employees not really expect these incentives because of the uncertainty of PT Lestari Jaya Raya in terms of providing incentives.

4) The independent variable of work discipline affects the performance of employees at PT Lestari Jaya Raya. With the high, it can be concluded that the higher the level of work discipline in PT Lestari Jaya Raya employees, the higher the results of the employee's performance.

\section{Limitation and study forward}

This research is limited to the staff office of PT Lestari Jaya Raya so it has not described the overall condition of the employees of PT Lestari Jaya Raya which consists of staff office and staff operational. Future researchers may conduct research that may be able to focus on independent variables that have not been affected in this study, namely internal control and incentives. This can be done on the subject 
of other companies or institutions in order to ensure that there is an influence between internal control, incentives, and employee performance

\section{Acknowledgment}

Thank you to my family, colleagues, and to my lecturer who have helped me for the smoothness and perfection of this study.

\section{References}

Alawaqleh, Q. A. (2021). The Effect of Internal Control on Employee Performance of Small and Medium-Sized Enterprises in Jordan: The Role of Accounting Information System. Journal of Asian Finance, Economics and Business, 8(3), 855-863. https://doi.org/10.13106/jafeb.2021.vol8.no3.0855

Banjoko, S. (2006) Managing Corporate Reward Systems, Lagos: Pumark Nigeria Limited.

Chang, S. I., Yen, D. C., Chang, I. C., \& Jan, D. (2014). Internal control framework for a compliant ERP system. Information Management, 51(2), 187-205. https://doi.org/10.1016/j.im.2013.11.002

Committee of Sponsoring Organization (COSO) of The Treadway Commission. 2013. Internal Control - Integrated Framework: Executive Summary. COSO. Mei 2013.

Fathia, M., Suharto, \& Sodikin, A. (2018). Effect of leadership and discipline on employee performance through employee organization commitment Bank Jabar Banten ( BJB ). International Journal of Multidisciplinary Research and Development, 5(2), 130-139.

Ghozali, I. \& Latan, H. (2015). Partial Least Square Konsep, Teknik dan Aplikasi Menggunakan Program SmartPLS 3.0 Untuk Penelitian Empiris (VOL. 2). Semarang: Universitas Diponegoro Semarang.

Halim, A., Tjahjono, A., \& Husein, M. F. (2000). Sistem Pengendalian Manajemen. Yogyakarta: Sekolah Tinggi Ilmu Manajemen YKPN.

Hariandja, Marihot Tua Efendi. (2002). Manajemen Sumber Daya Manusia. Jakarta: Grasindo.

Hasibuan, Malayu. (2007). Manajemen Sumber Daya Manusia. Jakarta: PT Bumi Askara.

Hormati, T. (2016). Universitas sam ratulangi manado mei, 2016. Jurnal EMBA, 4(2), 236-253.

Ida Aryati, Y. Y. I. (2017). Pengaruh Insentif, Disiplin Kerja, Dan Komunikasi Terhadap Kinerja Karyawan Bagian Sewing Pt. Pelita Tomangmas Karanganyar. Jurnal Akuntansi Dan Pajak, 18(01), 145-157. https://doi.org/10.29040/jap.v18i01.92

Iskandar Rifai, V.V Rantung, W. R. (2016). Pengaruh Insentif Individu Terhadap Kinerja Karyawan PT Summit Oto Finance Bitung.Jurnal Ilmu Sosial \& Pengelolaan Sumberdaya Pembangunan. Jurnal Ilmu Sosial \& Pengelolaan Sumberdaya Pembangunan, 21, 63-80. Issn : 2337 - 4004. April, 63-80.

Mathis, Robert L, dan Jackson, John R. Human Resources Management, 10th edition, South-Western, Ohio - Penerjemah: Diana Angelica, Penerbit Salemba Empat, Jakarta, 2004-2006.

Merchant, Kenneth A. \& Wim A. Van Der Stade. (2014). Sistem Pengendalian Manajemen: Pengukuran Kinerja, Evaluasi, dan Insentif. Jakarta: Salemba Empat.

Oloke, O. C., Oni, A. S., Babalola, D. O., \& Ojelabi, R. A. (2017). Incentive Package, Employee's Productivity and Performance of Real Estate Firms in Nigeria. European Scientific Journal, ESJ, 13(11), 246. https://doi.org/10.19044/esj.2017.v13n11p246

Olufunmilayo, A. A., \& Hannah, O. O. (2018). Effect of Internal Control System on Employee Performance of Small-Scale Manufacturing Enterprises in Ondo State, Nigeria. Human Resource Research, 2(1), 48. https://doi.org/10.5296/hrr.v2i1.13016

Permatasari, J. (2015). PENGARUH DISIPLIN KERJA DAN MOTIVASI KERJA TERHADAP PRESTASI KERJA KARYAWAN (Studi pada PT BPR Gunung Ringgit Malang). Jurnal Administrasi Bisnis S1 Universitas Brawijaya, 25(1), 86139.

Reginato, L., \& Guerreiro, R. (2013). Relationships between environment, culture, and management control systems. International Journal of Organizational Analysis, 21(2), 219-240. https://doi.org/10.1108/IJOA-02-2011-0477

Robbins, Stephen P. (2010). Manajemen. Edisi 10. Jakarta: Erlangga.

Sagala, F. Z. (2020). The Effect Of Accounting Information Systems And Internal Control Of Employee Perfomance. Jurnal Akuntansi, Audit Dan Sistem Informasi Akuntansi, 4(1), 69-81.

Sengkey, G. (2013). Pengaruh Penerapan Sistem Pengukuran Kinerja Dan Sistem Penghargaan 
Terhadap Kinerja Karyawan Di Pt.Bank Sulut Cabang Amurang. Jurnal Riset Ekonomi, Manajemen, Bisnis Dan Akuntansi, 1(4), 1509-1519. https://doi.org/10.35794/emba.v1i4.2953

Siagian, Sondong P. (2006). Manajemen Sumber Daya Manusia, Jakarta: Bumi Askara.

Singodimedjo. (2012). Manajemen Sumber Daya Manusia. Jakarta: Ghalia.

Sugiyono. (2015). Statistika Untuk Penelitian. Bandung: Alfabeta.

Tackett, J. A., Wolf, F. M., \& Claypool, G. A. (2006). Fraud specialists on independent audits. Journal of Business Economics Research, 4(7), 68-86. https://doi.org/10.19030/jber.v4i7.2686 